Doi: $10.4274 /$ Vhd. 58966

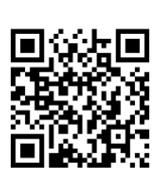

\title{
Hepatit Virüsleri için Dezenfeksiyon Yöntemleri ve Uygulamaları
} Disinfection Methods and Applications for Hepatitis Viruses

\author{
Merih ŞIMŞEK, Nedim SULTAN \\ Gazi Üniversitesi Tıp Fakültesi, Tıbbi Mikrobiyoloji Anabilim Dalı, Ankara, Türkiye
}

\section{ÖZET}

Hepatit virüslerinin hedef organı karaciğerdir. Hepatositlerde çoğalarak farklı düzeylerde karaciğer harabiyetine yol açmakta ve benzer hepatit bulgularına neden olabilmektedirler. Günümüzde yapıları, hücrede çoğalma şekilleri, bulaş yolları, hastalık süreçleri ve neden oldukları sekeller bakımından birbirinden farklı $A, B, C, D, E$ ve $G$ virüsleri bilinmektedir. Bugün için milyarlarca insanın bu virüslerden biri ile enfekte olduğu bilinmektedir. Hepatit virüsleri bulaşma şekli bakımından iki grupta incelenebilir. B, C, D ve G grubunda yer alan virüsler temel olarak parenteral yolla, A ve E virüsleri ise oral fekal yolla bulaşmaktadırlar. $\mathrm{Bu}$ yazıda hepatit virüslerinin bulaşma yolları temel alınarak bulaşmalarının önlenmesi için uygulanması gereken dezenfeksiyon yöntemleri literatür bilgileri ışığında gözden geçirilmiş ve öneriler sunulmuştur. (Viral Hepatit Dergisi 2013; 19(2): 37-42)

Anahtar Kelimeler: Hepatit virüsleri, dezenfeksiyon, bulaşma yolları

\begin{abstract}
Hepatitis viruses lead liver damage at different levels and may cause similar hepatitis symptoms by multiplying in hepatocytes. Nowdays, A, B, C, D, E, and $G$ viruses are known in different terms of structures, cell proliferation patterns, transmission routes, disease processes and sequels that they may cause. It is known that billions of people are infected with one of these viruses for today. Hepatit viruses can be studied in two groups in point of transmission route. Viruses which take part in $B, C, D$ and $G$ groups are basically transmitted via the parenteral route, whereas $A$ and $E$ viruses are transmitted via the oral-fecal route. In this article, the disinfection methods which should be applied for the prevention of infections are reviewed in the light of the literature on the basis of transmission routes, and recommendations are presented. (Viral Hepatitis Journal 2013; 19(2): 37-42)
\end{abstract}

Key words: Hepatitis viruses, disinfection, transmission routes

\section{Giriş}

Gelişmiş ve gelişmekte olan ülkelerde viral hepatitler önemli bir sağlık sorunu olmaya devam etmektedir. Günümüzde viral hepatite neden olan ve temel hedefi karaciğer olan en az 5 farklı virüs bulunmaktadır. Akut viral hepatite en sık neden olan viral hepatit virüsleri, hepatotropik virüslerdir. Bu virüsler, genomik yapısı, replikasyon döngüsü ve klinik özellikleri bakımından farklıık gösteren 5 ayrı virüs ailesinin üyesidirler. Bunlar $A, B, C, D, E$ olarak sınıflandırılırlar. $G$ hepatit virüsü olarak bilinen altıncı bir virüsün karaciğer hastalığı yapıp yapmadığı konusunda kuşkular giderilmemiştir. Bunların dışında diğer organ ve sistemlerde enfeksiyon oluşturan ve nadiren sarlığa neden olan virüsler de vardır. Bunlar HSV (Herpes Simplex Virus), CMV (Cytomegalovirus), EBV (Epstein Barr Virus), TTV (Transfusion-Transmitted Virus), VZV (Varisella Zoster Virus), HIV (Human Immunodeficiency Virus), kızamık, kızamıkçık, Coxsackie B, adenovirüs, enterovirüs, parvovirüs B19 ve arbovirüsler gibi virüslerdir (1).

Hepatit virüsleri insanlara çok çeşitli yollardan bulaşabilmektedir. Dezenfeksiyon işlemleri virüs bulaşının önlenmesinde büyük önem taşımaktadır. Dezenfektanlar virüsün protein yapısını ya da genom yapısını bozarak etkili olmaktadır. Dezenfeksiyon etkinlik testleri yapılırken enfektivite düzeyi hücre kültürlerinde değerlendirilebilmektedir. Ancak bazı virüslerin laboratuvar da üretilememesi nedeniyle bu virüslerin dezenfektanlardan etkilenme 
düzeyleri genom ve protein yapılarındaki değişim incelenerek değerlendirilebilmektedir. Ayrıca incelenen virüsün enfekte edebildiği deney hayvanları da kullanılabilmektedir. Dezenfeksiyon işlemi yapııırken mekanik etkilerin göz ardı edilmemesi gerekmektedir. Yüzeyin organik yükü, nem oranı, kuruluk durumu, yüzey yapısı, hücresel kalıntılar, ortamın pH'sı, iyonik kuvvetler ve ortam ISISı kontrol altında olması gereken değişkenlerdir (2-5).

Etkili dezenfeksiyon yöntemlerinin kullanılması bu virüslere bağlı enfeksiyonların ortaya çıkmasını azaltacaktır. Yetersiz dezenfeksiyon uygulamaları nedeniyle ortaya çıkabilen enfeksiyonların uygun ve doğru dezenfeksiyon yöntemleri ile önlenmesi ülke ekonomileri açısından da önem taşımaktadır. Bir tek hastanın tedavi maliyeti ile çok sayıda yeni enfeksiyonun oluşması bu yolla önlenebilmektedir.

\section{Hepatit A Virüsü}

Hepatit A Virüsü (HAV), pikornavirüs grubunda heparnavirüs cinsi içinde incelenir. HAV tek iplikli bir RNA virüsüdür. Zarfsız bir virüs olup birincil hedefi hepatositlerdir. Bir tek serotipi vardır. HAV fekal-oral yolla bulaşır ve enfeksiyonları oldukça yaygındır. Hepatit A virüsü yetersiz hijyen koşullarında kolaylıkla yayılan bir virüstür. Akut hepatitlerin yaklaşık \%40' ı HAV' a bağlı gelişir (6)

$\mathrm{HAV}$, çevre koşullarına ve dezenfeksiyon işlemlerine karşı diğer virüslere göre daha dayanıklıdır. Kuruluğa, eter ve kloroform gibi solventlere, deterjanlara, $\mathrm{pH} 1$ kuvvetindeki asitlere dirençlidir. Diğer pikornavirüslerden daha dayanıklıdır. Virüs, yüksek ısı, formalin ve klorda inaktive olmaktadır. HAV, buzdolabında aylarca, organik maddeler içinde günlerce canlı kalabilmektedir. Canlılığını $-20^{\circ} \mathrm{C}^{\prime} \mathrm{de}$ yıllarca koruyabilmektedir. Dondurma işlemine dayanıklıdır $(2,7)$.

HAV, deniz kabuklularında, tatlı su, deniz suyu ve kaynak sularında aylarca canlı kalabilir. Midye, istiridye gibi deniz kabukluları bulaşmasında önemli yer tutar. Sularda uzun süre canlı kalabilmesi bulaşmasını kolaylaştırmaktadır (6-10). HAV ellerde ve kusmukta canlılığını günlerce sürdürebilmektedir. Ancak $85^{\circ} \mathrm{C}$ 'nin üstündeki sıcaklıklarda inaktive olmaktadır. Virüs, deniz suyunda, göl ve havuzlarda, ayrıca içme ve kullanma sularında, atık sularda ve toprakta bulunabilir. Kültürü yapılamamaktadır. Hayvan model sistemi yoktur $(7,10)$.

Insan dışkısı ile kontamine olan sularla sulanan sebzeler aracılığıyla HAV kolaylıkla bulaşabilmektedir. Bu nedenle evde ve lokantalarda tüketilen ya da gıda fabrikalarında tüketim için işlenen marul, çilek, domates gibi sebze ve meyvelerin dezenfekte edilmesi önem taşır (10). Klor virüsün protein ve genom yapısını bozan bir dezenfektandır ve dezenfeksiyon uygulamalarında yaygın kullanılmaktadır (11). HAV bulaşmasına aracılık edebilen meyve ve marul gibi sebzelerin 2 dakika boyunca 15 ppm serbest klor içeren suda bekletilmesi yada 100 ppm perasetik asitli suda bekletilmesi HAV inaktivasyonunda etkili olmakla birlikte istenen ve güvenli düzeylerde bir sonuç verememektedir. Bu nedenle toplu gıda işlenen fabrikalarda halen güvenli dezenfeksiyon sağlayacak teknolojilerin geliştirilmesine gereksinim duyulmaktadır. Sadece su ile yıkamanın ancak 0.7 log'luk bir virüs azalmasına neden olduğu ve koruyucu olamayacağı belirlenmiștir $(12,13)$. Kısa süreli 20 ppm serbest klor içeren su ile yıkanan sebze ve meyvelerdeki HAV'ın \%90 oranında inaktive olduğu, sebze ve meyvelerin 5-10 dakika süre ile 200 ppm klorlu suda bekletilmesinin ise virüs inaktivasyonunda tam etkili olduğu belirlenmiştir (14).

HAV'ın kan ve serum kalıntılarıyla bulaştığı da bilinmektedir. Sağlık personeli virüsün bulaşmasına aracılık edebilmektedir
Dezenfeksiyon uygulanan yıkama makinelerinde kullanılan dezenfektanların etkisinin ısı artışı ile arttığı belirlenmiştir. HAV $85^{\circ} \mathrm{C}$ 'nin üzerindeki ısılarda süretle inaktive olmaktadır (15)

Kan ve serum gibi maddelerle bulaşmış materyaldeki HAV'ın inaktive edilmesi için taşıyıcı testi kullanılarak \%0,2 sodyum dodesil sülfat ve $\% 0,3$ sodyum hidroksit ile muamele etmenin virüs üzerine etkili olmadığı bulunmuştur. Ancak bu karışıma \%20 propanol katılmasıyla $20^{\circ} \mathrm{C}$ de 20 dakikalık uygulama sonunda virüs sayısında en az 4 log'luk bir azalma sağlandığı ve etkili inaktivasyon sağlandığı belirlenmiştir (16). Taşıyıcı testi, metal, katater, cam yada dokuma gibi malzemelerden standart büyüklükte hazırlanan bir parçanın test mikroorganizmasıyla bulaștıııması ve test dezenfektanında belirli süre bekletildikten sonra üzerindeki mikroorganizmanın ne derece inaktive edildiğinin incelendiği bir dezenfeksiyon etkinliği test yöntemidir.

HAV ve HEV su ile bulaşabildiklerinden suların dezenfeksiyonu önem taşır. Klor, ozon gibi kimyasal oksidanlar, suyun ısıtılması, UV ile ışınlama bu amaçla kullanılan yöntemlerdir. UV ile ışınlamada genom büyüklüğü etkilenme düzeyini belirler. Genom büyüdükçe etkilenme düzeyi artmaktadır. Yapılan incelemelerde klor ve ozon gibi oksidanların amino asit dizilişi üzerine etkili olduğu, buna karşılık ışınlamanın nükleik asit yapısı üzerine daha etkili olduğu belirlenmiştir (11).

HAV ile kontamine su ve diğer materyalin $100^{\circ} \mathrm{C}$ ye kadar Isıtılması virüsü inaktive etmektedir. Buna karşılık, $60^{\circ} \mathrm{C}$ de 30 dakika ısıtmak katı ve sıvı yiyeceklerde enfektif virüs sayısını 2 log seviyesinde azaltır. HAV, çiğ sütle de bulaşmaktadır. Çiğ sütün pastörizasyonu RT-PCR yöntemi ile yapılan incelemelerde \%90 nispetinde bir inaktivasyon sağlamaktadır. Bu düzeydeki inaktivasyon koruyucu olmamaktadır $(10,17)$. Katı gıda pastörizasyonu $\left(70^{\circ} \mathrm{C}^{\prime} \mathrm{de}\right.$, 2 dakika) ve süt pastörizasyonu $\left(71,5^{\circ} \mathrm{C}^{\prime}\right.$ de, 15 saniye) aktif virüs sayısını 2 log seviyesinde azaltabilmektedir. UHT ise $\left(120^{\circ} \mathrm{C}^{\prime}\right.$ nin üstündeki uygulamalar) tam etkili olmaktadır. Dondurma işlemi ve asidifikasyon ișlemleri HAV enfektivitesine etkisizdir. Bir dakikalık 0.5 ppm klorlu su enfektif virüs sayısında ancak 3 log'luk bir azalma sağlamaktadır. Yüzeylere \%70 alkol, \%00.5 klorheksidin ve \%0.125 sodyum hipoklorit konsantrasyonlarında 10 dakika uygulama yapılması da yeterli koruyucu etki sağlayamamaktadır $(5,10)$.

Deniz kabuklularına bağlı sık salgınlara neden olan bu virüsün inaktivasyonu için 15 kGy'lik gamma ışını uygulaması bile tam etkili olmamaktadır $(10,17)$. Şehir şebeke suyu 0,3-0,5 ppm klor ile gönderilmektedir. Ancak şebeke suyuna kanalizasyon sularının karışması halinde 0,5-1 ppm serbest klor düzeylerinin kirlilik varlığında süratle etki edemeyeceği belirlenmiştir. Bu nedenle bu özel hallerde 0,3 ppm düzeyinin koruyuculuğu olmamaktadır. Temiz sularda 0,5 ppm klorun, 3,6 dakikada HAV sayısında 4 log 10'luk redüksiyon yaptığı belirlenmiştir (18).

HAV, göl, kaplıca ve havuzlardan da bulaşabilmektedir. Havuz suyuna uygulanan 1 ppm'lik serbest klor konsantrasyonları yeterli koruma sağlamamaktadır (19). Çünkü havuz sularında farkı hijyen anlayışında çok sayıda insanın yüzdüğü ve sürekli bir kirlenme ile havuz suyunda organik madde birikmesi klorun etkinliğini daha da azaltmaktadır. Ancak 1 ppm'den daha fazla klor uygulanması da hem suyun kalitesini bozmakta hem de insan sağlığı açısından problem yaratmaktadır. Bu nedenle yüzme havuzlarında sürekli su değişimi, suya girenlerin hijyen kurallarına uymasının sağlanması da önem taşımaktadır. 
Virüs bulaşmasının önlenmesinde yüzeylerin dezenfeksiyonu önem taşımaktadır. Taşıyıcı testleri kullanılarak yapılan testlerde alınan sonuçlara göre kontamine yüzeyler, yerler ve lavabolar \%2 gluteraldehit, \%23 HCL içeren dörtlü amonyum bileşikleri ve 5000 ppm'den daha yoğun sodyum hipoklorit ile temizlenirse \%999'luk bir inaktivasyon sağlamaktadır. Bu düzey güvenilir bir koruma sağlamaktadır. Buna karşılık HAV ile kontamine yüzeylere, fenol bileşikleri, alkoller, iyotlu ürünler, asetik, perasetik, sitrik ve fosforik asitlerin bir etkisi olmamaktadır (20).

HAV enfeksiyonları şehirlerin modern alt yapıya kavuşturulması, fekal atıkların içme suyu kaynaklarına ulaşmasının engellenmesi, şehir sularının ozonlandıktan sonra klorlanarak tüketime sunulması ile büyük ölçüde kontrol altına alınır. Şehir suyu şebekesinin sızdırmaz ve sağlam malzemeden yapılması ve menfi basınca neden olan su kesintilerinin önüne geçilmesi gereklidir. Sebze ve çilek gibi bazı meyvelerin fekal atıkların kirlettiği sularla sulanmasına izin verilmemelidir. Su ürünlerinin tüketildiği göl ve nehirlerinde fekal atıklardan korunması lazımdır.

\section{Hepatit B Virüsü}

Hepatit B (HBV) virusu Hepadnaviridae ailesinde yer alır. Bu virüs zarflı, küresel bir DNA virüsüdür. Replikasyonu hepatositler içinde olur. Akut ve kronik hepatite neden olur. Nükleokapsid ve kordan oluşan Dane partikülü ile bulaşır (2).

Hepatit B tüm dünyada en yaygın görülen enfeksiyon hastalıklarından biridir. Dünya nüfusunun üçte biri bu virüs ile enfekte durumdadır (21). Her yıl yaklaşık 1 milyon insan HBV enfeksiyonu nedeniyle ölmektedir. Afrika ve Güney Doğu Asya en yaygın görüldüğü bölgelerdir (6). HBV, asemptomatik taşıyıcıların kan ve diğer vücut salgılarında bulunmaktadır. Kan ve kan ürünleri transfüzyonu, intravenöz ilaç kullanıcılarında ortak enjektör ve iğne kullanımı, hemodiyaliz, akupunktur, pirsing ve dövme uygulamaları, sağlık personelinde iğne batması, kesici alet yaralanması bulaşma nedeni olabilmektedir. Semen, tükrük ve vajinal salgılarda bulunması cinsel temasla bulaşmasına neden olmaktadır (6). Taşıyıcı anneden bebeğe doğum esnasında ya da emzirme ile sütten de geçebilmektedir (1).

HBV ile kontamine materyal \%10'luk çamaşır suyu ile dezenfekte edilebilir. Zarflı olmasına rağmen diğer zarflı virüsler gibi deterjanlarla inaktive olmamaktadır (6).

Hepatit B virüsü de Hepatit C (HCV) virüsü gibi çevresel kontaminasyona bağlı olarak bulaşabilir. HBV'nin bu tür belirsiz temaslarla bulaşma riski HCV'ye göre daha yüksektir. Çünkü, HBV dış ortama daha dayanıklıdır. HBeAg pozitif olan kişilerin serumunda 108-1010 virion/ml virüs partikülü bulunur. Semen ve tükrükte de HBV bulunabilmektedir. Idrar, dışkı, süt, ter, gözyaşı, vajinal salgı, beyin omurilik sıvısı ve kordon kanında da virüs bulunmasına rağmen bunlarda, virüs yoğunluğunun düşük olması nedeniyle sadece semen ve tükrükle bulaşma riski olma olasılığı daha yüksektir $(5,15)$.

Ortak şırınga kullanan damar içi uyuşturucu kullanıcıları arasında HBV kolaylıkla bulaşabilmektedir. Central of Disease Control (CDC) önerilerine göre bulaşmanın önlenmesi için ortak kullanılan şırıngaların kullanılmadan önce deterjan ile temizlenip yıkanması, sonra 30 saniye \%5 sodyum hipoklorit içinde bekletilmesi ve daha sonra yıkanması ile virüsün bulaşması engellenebilir (22). Ancak tek kullanımlık şıııngaların kullanılması en güvenli yöntemdir
(23). Intravenöz ilaç kullanıcılarında bu yolla kanda daha yüksek konsantrasyonda bulunan HBV ve HCV'nin HIV virüsüne göre bulaşma olasııkları daha yüksektir. Hastalara bulaşmanın önlenmesi için önerilen koruyucu yöntemler (sterilleyici fırın, pamuk, yıkama suyu, yeni turnike, antiseptik kullanımı) ilaç etkisi ile kendinde olmayan bu hastalar tarafından etkili bir şekilde kullanılamamaktadır (23).

Toplumun \%1'ine endoskopi yapılmaktadır. HBV ve HCV çok kanallı kompleks yapılı endoskoplar ile bulaşabilmektedir. Mide ve barsak endoskopisi sonrası HBV ve HCV enfeksiyonu alındığına ilişkin literatür bilgileri bulunmaktadır $(21,23,24)$. O nedenle endoskoplara etkili dezenfeksiyon yapılması bulaşın önlenmesi açısından önem taşımaktadır.

Endoskoplarla HBV geçişi nadirdir. Standart işlemlerle geçiş engellenmektedir. Bu işlemler enzimatik yıkama, su ile yıkama, \%2 gluteraldehit ile 10 dakika dezenfeksiyon ve sonra tekrar su ile yıkama ve en son kurulamayı içermektedir (25).

Endoskopların \%0,065 konsantrasyonda perasetik asit ile 1 saat tutulması sonucu HBV'nin protein ve genom yapısında ciddi hasarlar oluştuğu ve virüs enfektivitesin de en az 4 log' luk bir azalma olduğu belirlenmiştir (26). Bu araştırmada enfektivite değişimi HBsAg epitoplarındaki azalma monoklonal antikorların kullanıldığı ELISA testi ile nükleik asit yapısındaki değişim PCR testi ile DNA'daki alterasyon (değişim) ve disintegrasyon (dağılma) düzeyleri ölçülerek yapılmıştır. Özellikle ortama serum eklendiğinde yani kir varlığında antiviral etkinin azaldığı görülmüştür. Bu nedenle uygulama süresinin 60 dakika kadar uzun tutulması ile perasetik asitin hem epitop düzeyinde hem de genom virüs yapısında enfektiviteyi yok eden bir etki göstermesi sağlanmıştır. Dezenfeksiyon işlemi öncesi aletlerin ön yıkama ve temizlik işleminden geçirilmesi dezenfeksiyon etkinliğini arttırmaktadır (26).

Kuru plazma kirlilik faktörü varlığında yüzeylere 10 dakika süre ile 500 ppm klor uygulanması ile 6 log'luk bir HBV redüksiyonu saptandığı belirlenmiştir. Bu konsantrasyonda ki serbest klor enfekte materyaldeki virüsleri etkin bir şekilde inaktive edebilmektedir (18).

CDC, hemodiyaliz üniteleri, endoskop ve dental ekipmanın dezenfeksiyonu için 20 dakika süreyle \%2'lik gluteraldehit kullanımı önermektedir (27).

HBV'nin hücre kültürü çok zor yapılabilmesi ve pek uygulanamaması nedeniyle bu virüse etkili antiviral ajanların etkisi şempanze enfektivite testi ile araştırılabilmektedir. Bu test yönteminde bir süre dezenfektan yada antiviral ajan uygulanan malzemelerin aseptik koşullarda elde edilen yıkama sularının sulandırımları hazırlanarak şempanzeye verilmekte ve hayvanda enfeksiyon gelişip gelişmediği izlenerek dezenfektan etkinliği ölçülebilmektedir.

Şempanze enfektivite testi uygulanarak yapılan bir çalışmada, hazırlananvirüs süspansiyonuna 5 dakika süreyle $\% 1$ gluteraldehit uygulanması, 2 dakika süreyle $98^{\circ} \mathrm{C}$ de ısıtma işlemi uygulanması yada 2 dakika süreyle \%80'lik etanol uygulanması işlemlerinin enfektiviteyi tamamen ortadan kaldırdığı belirlenmiştir (28).

Dişhekimliği uygulamalarında kullanılan modüllerdeki aeratör, kavitron gibi aletlere ve modül yüzeylerine $\% 80$ etanol ve $\% 5$ isopropanol içeren spreylerin dezenfeksiyon amacıyla uygulanması, yüzeylere bulaşmış olabilen HBV ve HCV'yi inaktive etmektedir. Yüzde 80 etanol konsantrasyonu, \% 70'lik konsantrasyondan daha etkili bulunmuştur. Bu formüle \% 5 n-propanol ilave edilmesi 
dezenfektanın etki gücünü arttırmakta ve dezenfeksiyon etki süresini kısaltmaktadır (29).

Şempanzelerde yapılan farklı bir çalışmada virüse 10 dakika süre ile uygulanan 703 ppm dörtlü amonyum bileşiği ve 356 ppm fenolik bileşiği karışımının HBV enfektivitesini tamamen yok ettiğini gösterilmiştir (30). Yine şempanze enfektivite testi kullanılarak yapılan deneylerde \% 70'lik isopropanol ile orta düzey dezenfeksiyon ve \%2 gluteraldehit ile yüksek düzey dezenfeksiyon işlemlerinin de virüs enfektivitesini etkili bir şekilde ortadan kaldırdığı belirlenmiştir (31).

HBV'nin \%1 gluteraldehit ile 5 dakikada, \%80 etanol ile 2 dakikada, $98^{\circ} \mathrm{C}$ de ısıtılmakla yine 2 dakikada inaktive olduğu belirlenmiştir. HBV'nin, \%1'lik sodyum hipoklorit ve \%70'lik izopropil alkol ile inaktive olduğu ancak, UV, eter ve benzalkonyum kloride nispi direnç gösterdiği belirlenmiştir (15).

Duck Hepatitis B Virusü (DHBV), hepatosit kültüründe üretilebildiği için HBV ile yapılan enfektivite testlerinde örnek virüs olarak kullanılabilmektedir. Dezenfektanların etkisi incelenirken, virüs HBsAg epitoplarındaki azalma ve nükleik asitlerindeki değişim ve dağılma düzeyleri değerlendirilmektedir. Kantitatif PCR ile modifiye olmuş nükleik asit dizilerinin amplifikasyonundaki blokaj ölçülerek de değerlendirme yapılabilmektedir $(5,32)$.

$\mathrm{HBV}$, en kolay kan ve kan ürünleri ile bulaşmaktadır. HBV enfeksiyonu olan hastalardan alınan kan ve vücut sıvılarının naklinde laboratuvarlarda işlenmesinde özel dikkat sarf edilmesi gerekmektedir. Bu nedenle hemodiyaliz ünitelerinde kan merkezlerinde çalışan personelin bu virüslerin bulaşma yolları konusunda özel eğitim alması ve etkili dezenfeksiyon yöntemlerini uygulamaları büyük önem taşır. Sağlık personeli hasta temasından önce ve sonra ellerini yıkamalıdır. Alkol bazlı antiseptiklerle ellerini ovuşturarak temizlemelidir. Böylece hem kendilerini hem de hastalarını koruyabileceklerdir.

\section{Hepatit C Virüsü}

Hepatit C virüsü (HCV), Flaviviridae ailesine ait Hepacivirus cinsinin üyesidir. HCV zarflı bir RNA virüsüdür. Dünya nüfusunun \%3'ü HCV ile enfekte durumdadır. Her yıl 1 milyon yeni HCV enfeksiyonu ortaya çıkmaktadır. Kronikleşme eğilimi yüksek olan bir enfeksiyondur.

Kan ve ürünleri temel bulaş kaynağıdır. Seksüel temas ile daha nadir bulaşır. Sağlık personelinin kontamine elleri, hemodiyaliz makineleri ve diğer tıbbi malzemeler hastanelerde bulaş kaynağı olabilmektedir (33). HCV en çok kan ve kan ürünleri transfüzyonu, organ transplantasyonu, ortak enjektör ile uyuşturucu kullanımı, dövme yaptırma, kaza ile iğne batması, doğumda anneden bebeğe geçiş, hemodiyaliz uygulaması ve cinsel ilişki sonucu bulaşmaktadır. Virüs ayrıca tükrük, idrar ve semen gibi vücut sıvılarında da bulunmaktadır. Enfekte anne sütünde HCV bulunmaktadır. Ancak viral yükün sütte düşük olması nedeniyle enfeksiyona neden olmayacağı düşünülmektedir (34). Mısır'da kan donörlerinin \%20'sinde Anti HCV saptanmaktadır. Seroprevalansının en yüksek olduğu ülkeler Italya, Ispanya, Orta Avrupa Ülkeleri, Japonya ve Orta Doğu Ülkeleridir (6).

Enfeksiyöz virüsün çevreyi bir rezervuar olarak kullandığı saptanmıştır. Yüzeyler üzerinde kurumuş halde bir süre bekletilen kanda oda ısısında HCV enfektivitesinin devam ettiği gösterilmiştir (35). Ayrıca kronik hemodiyaliz tedavisi alan hastalarda HCV prevalansının yüksek olması çevresel kaynaktan bulaşma riskini güçlendirmektedir (36).

HCV'nin histeroskopi sırasında kullanılan kontamine histeroskoplarla bulaştığı bilinmektedir. Bir çalışmada 10 dakika süre ile $5 \times 10^{5} \mathrm{HCV}$ partikülü içeren $1 \mathrm{ml}$ serum histeroskop kanalında bekletilmiş, daha sonra 15 dakika deterjan içinde bekletilmiş ve kanal fırçalandıktan sonra $2 \mathrm{ml}$ distile su ile yıkanmıştır. Uygulamadan sonra histereskopların \%3'ünde enfekte virüs varlığı belirlenmiştir. Buna karşılık \%2 gluteraldehit içinde 20 dakika bekletilen kontamine histereskopların virüsten tamamen arındığı belirlenmiştir (37).

CDC, HCV'nin de HBV gibi ortak şırınga kullanan ilaç kullanıcılarına da bulaşmaması için şııngaların kullanılmadan önce deterjan ile temizlenip yıkanması, 30 saniye $\% 5$ sodyum hipoklorit içinde bekletilmesi ve daha sonra yıkanmasını önermektedir (22).

HCV ile oda yüzey materyali kontamine edildikten sonra oda ısısında enfektivitenin 8 günde 10 misli azalırken, $37^{\circ} \mathrm{C}$ de 2 günde yaklaşık 2 log seviyesinde azaldığı belirlenmiştir. Dört ${ }^{\circ} \mathrm{C}$ de ise enfektivite 147 gün devam etmektedir. Yüzeye serum eklenmesi enfektivite süresini etkilememiştir. Altmış beş ${ }^{\circ} \mathrm{C}^{\prime}$ de enfektivite etkilenmezken $75^{\circ} \mathrm{C}^{\prime}$ de enfektivitenin 100 kat azaldığı belirlenmiştir. Binde beş gluteraldehit veya \%0,05 perasetik asit ile 1 dakikalık uygulamaların enfektiviteyi ortadan kaldırdığı görülmüştür. Alkol, HCV'ye \%50 konsantrasyonun üstünde etkili olabilmektedir (38). Bir çalışmada HCV'nin cansız yüzeylerde 5-7 gün enfektif kaldığı, 70 derecede ısıtmak ya da 15 dakikalık \%70'lik 1-propanol uygulaması ile enfektivitenin kaybolduğu ve bu uygulamaların intravenöz ilaç kullananların şııngalarının dezenfeksiyonu için uygun olabileceği belirlenmiştir. Önerilen konsantrasyondaki gluteraldehit, dörtlü amonyum bileşikleri ve perasetik asitinde HCV' ye etkili oldukları taşıyıcı testleri kullanılarak gösterilmiştir. Ayrıca, 1-propanol, etanolden daha etkili bulunmuştur (39).

Dental uygulamalarda, \%80 etanol, \%5 isopropanol spreylerinin, diş ünitesi aletleri ve yüzeylerine uygulanması HBV gibi HCV'yide inaktive etmektedir. Bu karışıma \%5 n-propanol eklenmesi karışımın, etki gücünü arttırmakta ve etki süresini kısaltmaktadır (29).

HAV ve HBV hücre kültürlerinde üretilmelerinde büyük kısıtlııklar bulunmakta HCV ise hücre kültüründe üretilememektedir (6). Bu nedenle dezenfeksiyon etkinliği çalışmaları bu virüslere büyük ölçüde benzerlik gösteren virüsler kullanılarak yapılmaktadır. Zarflı bir virüs olan bovine viral diarrhoea virüs (BVDV), HCV virüsü modeli için, pseudo rabies virüsü de (PRV), HBV virüsü modeli için kullanılmaktadır (40). Yüzeyde hücre kültürü sıvıSı varlığında kurutulmuş olan zarflı virüsler olan BVDV ve PRV ile zarfsız bir virüs olan HAV virüsleri üzerine $0,1 \mathrm{~N} \mathrm{NaOH}$ ve $\% 0,1^{\prime}$ lik hipoklorit uygulamasının güçlü bir etki sağladığı belirlenmiştir. Aynı çalışmada \%80'lik etanol'ün HAV virüsünü etkilemediği buna karşılık zarflı virüsleri 10 dakikada inaktive ettiği belirlenmiştir. Ancak yüzeylerde kurutulmuş virüslere karşı etanol' ün etkisi daha zayıf bulunmuştur. Virüslerin plazma varlığında kurutulması durumunda tüm dezenfektanların etki süresi uzamaktadır. Kirli yüzeylerin hızla temizlenmesi dezenfeksiyon etkisini arttırmaktadır. Dezenfeksiyon öncesi kuru yüzeylerin önce suyla ıslatılması ya da sabunla temizlenerek ıslatıması özellikle dental uygulamalarda dezenfeksiyon etkinliğine katkı sağlamaktadır (5).

Zarflı virüslerin kuru yüzeyde 1 hafta, zarfsız virüslerin ise bir aydan fazla enfeksiyöz kaldığı belirlenmiştir. Kuru yüzeylerde enfektivite korunmakta ve dezenfeksiyon zorlaşmaktadır (40). 
Temiz aletler, 30 dakika \%6'lık hidrojen peroksit içinde bekletilirse bütün virüsler ölmektedir. Sağlık personelinin hasta temasından önce ellerini alkol bazlı dezenfektanlarla dezenfekte etmeleri eller aracılığıyla HCV geçişini engelleyebilmektedir (41).

\section{Hepatit D Virüsü}

Hepatit D virüsü (HDV), satellit virüs grubu olan Deltavirüs cinsinde sınıflandırılır. Bu virüs, zarflı ve tek iplikli bir RNA virüsüdür. Zarfı HBsAg'den oluşur. Nükleokapsid kısmı ise HDAg ve RNA'dan oluşur. Fulminan hepatitlerin \%40'ından sorumlu olduğu düşünülen HDV hepatositleri enfekte etmektedir $(2,6)$.

HDV kendi zarf proteinlerini kodlayamaz. Ancak HDV yardımcı virüsü HBV ile ortak sekans paylaşmaz. HBV'nin yokluğunda replike olabilir ama virüs partikülleri oluşamaz. HDV'nin zarfı HBV'nin yüzey antijenlerinden oluştuğu için karaciğer hücrelerini enfekte etmek için HBV ile aynı reseptörleri kullanır. Bu nedenle HDV enfeksiyonu ya HBV ile birlikte koenfeksiyon şeklinde ya da HBsAg taşıyıcılarına sonradan bulaşarak süperenfeksiyon şeklinde ortaya çıkar $(2,42)$.

Dünyadaki HBsAg taşıyıcılarının yaklaşık \%5'inde yani 20 milyona yakın insanda HDV enfeksiyonu bulunmaktadır (6). HBV aşısı ve diğer profilaktik önlemler, Italya, Ispanya, Türkiye ve Tayvan gibi ülkelerde HDV prevalansını düşürmüştür. Ancak endemik bölgelerden göç nedeniyle yeni yerleşim bölgeleri bulmuştur. Hepatit D, HBV'ye benzer olarak kan yada vücut sıvilarıyla parenteral yoldan bulaşmaktadır. Enfeksiyonu başlatan enfeksiyöz doz oldukça düşüktür. Damar yolu ile uyuşturucu kullananlarda, hemofili hastalarında ve homoseksüellerde bulaşma riski ve görülme sıklığı oldukça yüksektir. Seksüel yolla bulaşma gerçekleşebilmesine rağmen HIV ve HBV' de olduğu gibi belirgin değildir. Anneden bebeğe geçiş ise çok nadir olarak görülür (43). HDV enfeksiyonu ülkemizde özellikle Doğu ve Güneydoğu Anadolu Bölgeleri için ciddi bir sorundur (44).

HDV'nin bulaşmasını önlemek için HBV ve HCV bulaşmasını önlemek için uygulanan dezenfeksiyon yöntemlerinin uygulanması yeterli olmaktadır.

\section{Hepatit E Virüsü}

Hepatit E virüsü (HEV), Hepeviridae ailesinin tek cinsi olan hepevirus cinsinde yer alır. Zarfsız ve tek iplikli bir RNA virüsüdür. Virüs etere, kloroforma ve deterjanlara dirençlidir. $\mathrm{HEV}^{\prime}$ in hücrelere bağlanması, girişi ve replikasyon şekli tam olarak bilinmemektedir (45).

Hepatit E salgınlarının nedeni kontamine su kaynaklarıdır (5). Kontamine su kaynaklı salgınlar genellikle Hindistan, Burma, Nepal, Sudan, Etiyopya, Somali, Borneo gibi az gelişmiş ülkelerde görülmektedir $(6,46)$. HEV enfeksiyonları gelişmiş ülkelerde sporadik olarak görülmektedir. HEV, HAV gibi fekal-oral yolla bulaşmaktadır. HEV epidemilerinde enfeksiyon kaynağı genellikle kontamine su ve yiyeceklerdir. Sporadik olgular ise kontamine deniz ürünleri ve et tüketimi yada enfekte hayvanlarla doğrudan temas sonucu ortaya çıkmaktadır. Aile içi temas, cinsel temas bulaş nedeni olabilir. Bakımevi ve kreşlerde bulaş görülebilir. Kan transfüzyonu, damar içi ilaç kullanımı gibi nedenlerle nadir olarak bulaşabilir. Sağlıklı populasyonda \%1 olan mortalite oranı, hamilelerde \%20'ye kadar çıkmaktadır (6).
Yüzme esnasında göl, kaplıca ve havuzlardan bulaşabilmektedir. Havuzlarda uygulanan 1 ppm'lik serbest klor konsantrasyonları yeterli koruma sağlayamamaktadır (19). Zoonotik bir virüstür. Domuzlarda sık görülürken insanda nadir enfeksiyon yapar (10). HEV için, hayvan çiftliklerinin gübre atıkları önemli bir bulaş kaynağıdır. Insan gübresi de aynı tehlikeyi taşır. Bu gübrelerin \% 0,25-\%0,75' lik amonyakla 3 gün oda ısısında tutulması ile HEV enfektivitesi ortadan kaldırıbilmektedir. Bu uygulama tavuk ve domuz çiftlik atıkları için etkili bir uygulamadır (47).

HEV' de HAV gibi su ile bulaşabildiğinden suların dezenfeksiyonu önem taşır. Klor, ozon gibi kimyasal oksidanların kullanılması, suyun ısıtılması, UV ile ışınlama HEV enfeksiyonlarının bu yolla bulaşmasını engellemektedir (11).

HAV virüsünün bulaşmasının önlenmesi için alınan önlemler ve uygulanan dezenfeksiyon yöntemleri HEV virüsünün bulaşmasını önlemektedir. Ancak HEV zoonotik bir enfeksiyon olduğu için tavuk ve domuz çiftlikleri başta olmak üzere tüm besi çiftlik atıklarının kontrol altına alınması ve bu atıklara uygulanacak işlemlerin düzenlenerek kontrol edilmesi gerekmektedir.

\section{Hepatit G Virüsü}

Hepatit G virüsü (HGV), Flaviviridae ailesinde yer alan Hepacivirus cinsinin bir üyesidir. HCV' ye benzer özellikleri vardır. Zarflı bir RNA virüsüdür. Ülkemizde \%1 ile \%2 oranlarında taşıyıcılığı saptanmaktadır. Hemodiyaliz hastalarında daha yüksek oranlarda saptanmaktadır. Kan transfüzyonu yapılanlar, damar içi ilaç kullanıcıları, hemodiyaliz hastaları, hemofili hastaları, dövme ve akupunktur yaptıranlara bulaşabilmektedir. HGV, cinsel temasla da bulaşabilmektedir. Ayrıca perinatal geçişle anneden bebeğine bulaş görülebilmektedir. HGV, HBV ve HCV virüsleri ile birlikte bulunabilmektedir. Karaciğer hastalıklarındaki rolü netleşmemiştir $(6,48,49)$ Bu virüsün bulaşmasını önlemek için HBV ve HCV için uygulanan dezenfeksiyon uygulamaları yeterli olmaktadır.

\section{Çıkar Çatışması: Bildirilmemiştir.}

\section{Kaynaklar}

1. Curry PM, Chopra S. Acute viral hepatitis. In Mandell GL, Bennett JE, Dolin R (eds). Principle's and practice of Infectious Disesases. Philadelphia: Elsevier Churchill Li vingstone, 2005; 1426-41.

2. Badur S. Hepatit A, B ve D Virusları. Us D, Ergünay $K$ (eds). Moleküler Klinik ve Tanısal Viroloji.1. Baskı. Ankara: Bilimsel Tıp Yayınevi, 2012: 295-334.

3. Orozco G, Brödner R. Hepatitis viruses: not always what it seems to be.Rev Med Chil. 2010; 138(10): 1302-11.

4. Perçin D, Esen Ş. Güncel dezenfektanlar ve dezenfeksiyon uygulamalarındaki sorunlar. Ankem Derg 2009; 23: 89-93.

5. Virucide working groub at the Robert Koch Istitute. Testing and labeling of disinfectant activity against viruses. Bundesgesundheitsblatt 2004; 47(1): 62-66.

6. Ergon C, Abacıoğlu H. Hepatit Virüsleri. Başustaoğlu CA (ed). Tıbbi Mikrobiyoloji. 6.Baskı, Ankara: Atlas Kitapçılık, 2010: 645659.

7. Brundage SC, Fitzpatrick AN. Hepatitis A. AFP 2006; 73(12): 2162-8.

8. Yoldaş Ö, Bulut A, Altındiş M. Hepatit A Enfeksiyonlarına Güncel Yaklaşım. Viral Hepatit Dergisi. 2012; 18: 81-6.

9. Sharma S, Sachdeva P, Virdi JS. Emerging water-borne pathogens. Appl Microbiol Biotechnol. 2003; 61(6): 424-8. 
10. Koopmans M, Duizer E. Food borne viruses: an emerging problem. International. J. Food Microbiol. 2004; 90(1): 23-41.

11. Wigginton KR, Kohn T. Virus disinfection mechanisms: the role of virus composition, structure, and function. Curr Opin Virol. 2012; 2: 84-9.

12. Sattar SA, Jason T, Bidawid S, Farber J. Foodborne spread of hepatitis $A$ : Recent studies on virus survival, transfer and inactivation. Can J Infect Dis. 2000; 11(3): 159-63.

13 Fraisse A, Temmam S, Deboosere $N$, et al. Comparison of chlorine and peroxyacetic-based disinfectanttoin activate Feline calicivirus, Murine norovirus and Hepatitis A virus on lettuce. Int J Food Microbiol. 2011; 151(1): 98-104

14. Casteel MJ, Schmidt CE, Sobsey MD. Chlorine disinfection of produce to inactivate hepatitis A virus and coliphage MS2. Int J Food Microbiol 2008; 125(3): 267-73.

15. Çetin M. Hastanede sorunlu mikroorganizmalar: Viruslar ve prion. DAS Kongre kitabı, 2003.

16. Beekes $M$, Lemmer $K$, Thomzig A, Joncic M, Tintelnot $K$, Mielke M. Fast broad-range disinfection of bacteria, fungi, viruses and prions. J.Gen Vir. 2010; 91(2): 580-9.

17. Cliver DO. Early Days of Food and Environmental Virology. Food EnvironVirol. 2010; 2: 1-23.

18. Rutala WA, Weber DJ. Uses of Inorganic Hypochlorite (Bleach) in Health-Care Facilities. Clin Microbiol Rev. 1997; 10(4): 597610.

19. Sinclair RG, Jones EL, Gerba CP. Viruses in recreational waterborne disease outbreaks: a review. J Appl Microbiol. 2009; 107(6): 1769-80.

20. Mbithi JN, Springthorpes VS, Sattar SA. Chemical Disinfection of Hepatitis A Virus on Environmental Surfaces. Appl Environ Microbiol. 1990; 56(11): 3601-4.

21. European Centre for Disease Prevention and control. Hepatitis $B$ and $\mathrm{C}$ in the $\mathrm{EU}$ neighbourhood: prevalence, burden of disease and screening policies. ECDC Technical Report, Stockholm, 2010.

22. CDC Guideline for IDU/HIV. Prevention, Syringe disinfection for injection drug users. 2004; http://www.cdc.gov/idu

23. Vlahov D, Fuller CM, Ompad DC, Galea S, Jarlais DCD. Special Feature: Hepatitis C Virus. Updating the Infection Risk Reduction Hierarchy: Preventing Transition into Injection. Journal of Urban Health: Bull N Y Acad Med. 2004; 81(1): 14-9.

24. Morris J, Duckworth GJ, Ridgway GL. Gastrointestinal endoscopy decontamination failure and the risk of transmission of blood-borne viruses: a review. J Hosp Infect. 2006; 63(1): 1-13.

25. Dutta AK, Chacko A. Hepatitis B virüs transmission and processing of endoscopes, www.hepattisbannual.org 2013; IP:194.27.10.254

26. Jursch CA, Gerlich WH, Glebe D, Schaefer S, Marie O, Thraenhart O. Molecular approaches to validate disinfectants against human hepatitis B virus. Med Microbiol Immunol. 2002; 190(4): 189-97

27. Rutala WA, Weber DJ. Healthcare Infection Control Practices Advisory Committee (HICPAC). CDC Guideline for Disinfection and Sterilization in Healthcare Facilities, 2008.

28. Kobayashi H, Tsuzuki M, Koshimuzu K,et al. Susceptibility of Hepatitis B Virus to Disinfectants or Heat. J Clin Microbiol. 1984; 20: 214-6.

29. Moorer WR. Antiviral activity of alcohol for surface disinfection. Int J Dent Hyg. 2003; 1: 138-42.

30. Prince DL, Prince HN, Thraenhart O, Muchmore E, Bonder E, Pugh J. Methodological Approaches to Disinfection of Human Hepatitis B Virus. J Clin Microbiol. 1993; 31(12): 3296-304.
31. Bond WW, Favero MS, Petersen NJ, Ebert JW. Inactivation of Hepatitis B Virus by Intermediate-to-High-Level Disinfectant Chemicals. J Clin Microbiol 1983; 18(3): 535-38.

32. Wolff MH, Schmidt J, Rahaus M, König A. Hepatitis A virus: a test method for virucidal activity. J Hosp Inf. 2001; 48(Spull): 18-22.

33. Sulowicz W, Radziszewski A, Chowaniec E. Hepatitis C virus infection in dialysis Patients. Hemodial Int. 2007; 11: 286-95.

34. Croxson M, Couper A, Voss L, Groves D, Gunn T. Vertical transmission of hepatitis C virus in New Zealand. N Z Med J. 1997: 9: 165-67.

35. Kamili S, Krawczynski K, McCaustland K, Li X, Alter MJ. The infectivity of hepatitis $C$ virus after drying and storing at room temperature. Infect Control Hosp Epidemiol. 2007; 28(5): 51924.

36. Jadoul M, Roth D. Kidney Disease: Improving Global Outcomes. KDIGO Clinical practice guidelines for the Prevention, Diagnosis, Evaluation, and Treatment of Hepatitis C in Chronic Kidney Disease. Kidney Int. 2008; 73: 1-99.

37. Sartor C, Charrel RN, de Lamballerie $X$, Sambuc $R$, De Micco P, Boubli L. Evaluation of a Disinfection Procedure for Hysteroscopes Contaminated by Hepatitis C Virus. Inf Cont Hosp Epidem. 1999; 20: 434-6.

38. Ciesek S, Friesland M, Steinmann J, et al. How Stable Is the Hepatitis C Virus (HCV)? Environmental Stability of HCV and Its Susceptibility to Chemical Biocides. JID 2010; 201(12): 1859-66.

39. Doerrbecker J, Friesland J, Ciesek S, Erichsen TJ, et al. Inactivation and Survival of Hepatitis C Virus on Inanimate Surfaces. JID 2011; 204(12): 1830-8.

40. Terpstra FG, Blink AE, Bos LM, Boots AGC. Resistance of surface-dried virus to common disinfection procedures. J Hosp Infect. 2007; 66(4): 332-8.

41. Steinmann J, Becker B, Bischoff B et al.Virucidal activity of 2 alcohol-based formulations proposed as hand rubs by the World Health organization. Am J Infect Control. 2010; 381(1): 66-8.

42. Altunoğlu YÇ, Karataylı SC, Bozdayı M. Hepatit Delta Virüs Virolojisi: Taksonomi, Sınıflandırma, Yapısal ve Genomik Organizasyon, Viral Replikasyon, Viral Heterojenite, Deney Hayvanlarında Infeksiyon. Güncel Gastroenteroloji. 2011; 15: 241-4.

43. Niro GA, Fontana R, Ippolito AM, Andriulli A.Epidemiology and diagnosis of hepatitis D virus. Future Virology. 2012; 7: 709-17.

44. Değertekin H. HDV infeksiyonunun epidemiyolojisi ve korunma. Tabak F, Balık I Tekeli E (eds). Viral Hepatit. 1. Baskı. Istanbul: Oban Matbaası, 2005: 256-62.

45. Kırdar S. Hepatit E Virus Enfeksiyonu. Viral Hepatit Dergisi 2012; 18: $1-5$.

46. Kamar N, Bendall R, Legrand-Abravanel $F$, et al. Hepatitis E. Lancet. 2012;30;379(9835): 2477-88. Erratum In: Lancet. 2012 25;380(9843):730.

47. Emmoth E, Ottoson J, Albihn A, Belak S, Vinneras B. Ammonia Disinfection of Hatchery Waste for Elimination of SingleStranded RNA Viruses. Appl Environ Microbiol. 2011; 77: 3960-6.

48. Kandemir Ö. Non A-E Hepatit Virusları. Viral Hepatit Dergisi. 2005; 10: 125-34.

49. Ito K, Shimizu N, Watanabe K, Saito T, Yoshioka Y, Sakane E, et al. Analysis of viral infection by multiplex polymerase chain reaction assays in patients with liver dysfunction. Intern Med. 2013; 52(2): 201-11 